\title{
ECONOMIC AND POLITICAL REFLECTION ON THE BREXIT EFFECT EUROPE - PERU RELATIONSHIP
}

\section{Israel BARRUTIA BARRETO, PhD}

Innova Scientific, Lima, Peru

israel20barrutia@gmail.com

Hernán LARICO VERA, PhD

Universidad Nacional Federico Villareal, Peru

hernanlaricovera1@gmail.com

David Julio Martel ZEVALLOS, PhD

Universidad Nacional Hermilio Valdizán de Huánuco, Peru

martelzevallosd@gmail.com

\author{
Samuel Acevedo TORRES, PhD \\ Innova Scientific, Lima, Peru \\ sacevedo@innovascientific.com
}

\begin{abstract}
The key event that is expected to mark the beginning of the year 2021, will be the definitive transition out of the United Kingdom from the European Union, Brexit. Inquiring the key elements for a political and economic reflection, explained in terms of predictive mathematical models ARIMA, Holt-Winters and Lotka-Volterra, based on the historical variability of GDP in both nations from the Third Quarter of 2020 to the Third Quarter of year 2023. We show that the Republic of Peru will increase the variability in terms of gross domestic product GDP in relation to Brexit, with an exponential growth of 8,99\% in the study period; going from US \$195868,147 to US \$ 213478,795. In conclusion, Brexit is a special regime with an emphasis on transaction. In conclusion, Brexit is a special regime with an emphasis on transaction costs, measured as the GDP response of cross-border trade companies in the United Kingdom and especially in relation to Peru.
\end{abstract}

Keywords: Model, Prediction, Gross domestic product, Transition, Variability 


\section{Introduction}

The year 2020 marked the expected exit of the United Kingdom from the European Union (EU), this phenomenon is known as Brexit. Therefore, it is worthwhile to investigate the impact of Brexit on the stability of the euro zone and its future relationship with the post-Brexit Republic of Peru, given that a trade agreement between the two nations is currently in place (Adler, Galpin and Rosamond, 2017). This bilateral trade agreement between Peru and the United Kingdom continues to be administered by the Trade Agreement with the European Union while the agreement signed between the European Union and the United Kingdom formalizes the exit of the latter (Gidron and Hall, 2017).

As spectators and partners of a democratic system at the global level, the main focus is to distinguish between signs and echoes of the post-Brexit transition from the first day of January 2021, taking as a scenario the beginning of the Brexit era, Europe-Peru relationship (Hecht, 2016; Oehler, Horn and Wendt, 2017). Brexit can have a big impact on the UK financial markets, depending on how it evolves over time (Sowels, 2017). Tension is mounting as the days go by, as internal political divisions make it difficult to reach a common ground; however, the possibility of a Brexit on such terms would bring major complications for all parties involved. The international financial agency Fitch Rating pointed out that, with a "hard Brexit", the risks of Britain entering a deep recession increase, as the market faces some signs of decline, such as a drop in sales due to consumer caution, loss of confidence in financial institutions and, according to Vikram (2021), warnings of possible closures of the automotive manufacturing industry, as pointed out by Ford and Mini.

From the investigation, the research question arises: Will Brexit as a political and economic project allow the Republic of Peru to increase the variability in terms of gross domestic product (GDP)? This is a difficult and determining question. The contribution of this research is to provide some of the key elements for a political and economic reflection (Beaumont, 2017), which will be answered in terms of predictive mathematical models, starting from the historical variability of the GDP in both nations from the Third Quarter of the year 2020 and project to the Third Quarter of the year 2023 (Norris and Inglehart, 2019; Virdee and McGeever, 2017). 


\section{Methodology}

This is a documentary and descriptive type of research, since the data was located by consulting different types of historical documentation of the gross domestic product (GDP) (Horna, 2020), for Peru and the United Kingdom in the period 2016-2020 and projected for 2023, see Table 1. The empirical method used was observation and for data processing, descriptive, deterministic and stochastic statistical models (Ceballos and Rodriguez, 2020).

Table 1. Historical gross domestic product (GDP) for the United Kingdom and Peru, period 20162020.

\begin{tabular}{rcccccc}
\hline Period & $\begin{array}{c}\text { GDP-RU } \\
\text { M\$ }\end{array}$ & $\begin{array}{c}\text { Var. Qtly- } \\
\text { RU \% }\end{array}$ & $\begin{array}{c}\text { Var. Anu.- } \\
\text { RU \% }\end{array}$ & $\begin{array}{c}\text { GDP-PE } \\
\text { M\$ }\end{array}$ & $\begin{array}{c}\text { Var. Qtly-PE } \\
\text { \% }\end{array}$ & $\begin{array}{c}\text { Var. Anu.-PE } \\
\text { \% }\end{array}$ \\
Oct-2015 & $614.212,83$ & $0,40 \%$ & $2,50 \%$ & $168.985,32$ & $1,9 \%$ & $1,8 \%$ \\
Ene-2016 & $629.467,74$ & $0,20 \%$ & $2,10 \%$ & $172.101,72$ & $4,6 \%$ & $4,4 \%$ \\
Abr-2016 & $591.012,18$ & $0,60 \%$ & $2,20 \%$ & $185.804,08$ & $2,3 \%$ & $2,2 \%$ \\
Jul-2016 & $592.394,22$ & $0,10 \%$ & $1,10 \%$ & $187.009,48$ & $3,1 \%$ & $3,0 \%$ \\
Oct-2016 & $623.169,36$ & $0,70 \%$ & $2,00 \%$ & $191.684,72$ & $2,5 \%$ & $2,4 \%$ \\
Ene-2017 & $632.604,06$ & $-2,20 \%$ & $-1,70 \%$ & $172.434,00$ & $3,2 \%$ & $3,1 \%$ \\
Abr-2017 & $637.965,90$ & $0,50 \%$ & $2,30 \%$ & $190.826,00$ & $3,9 \%$ & $3,7 \%$ \\
Jul-2017 & $626.089,86$ & $0,50 \%$ & $1,90 \%$ & $176.576,36$ & $2,6 \%$ & $2,5 \%$ \\
Oct-2017 & $592.691,22$ & $0,30 \%$ & $1,90 \%$ & $196.209,11$ & $5,6 \%$ & $5,4 \%$ \\
Ene-2018 & $603.207,00$ & $0,50 \%$ & $1,30 \%$ & $189.253,59$ & $1,2 \%$ & $1,2 \%$ \\
Abr-2018 & $624.554,37$ & $-0,10 \%$ & $1,40 \%$ & $175.614,00$ & $3,2 \%$ & $3,1 \%$ \\
Jul-2018 & $519.808,41$ & $-20,40 \%$ & $-21,70 \%$ & $180.710,83$ & $4,8 \%$ & $4,6 \%$ \\
Oct-2018 & $645.976,98$ & $0,40 \%$ & $2,10 \%$ & $195.978,30$ & $2,7 \%$ & $2,6 \%$ \\
Ene-2019 & $583.366,41$ & $0,50 \%$ & $1,90 \%$ & $180.990,77$ & $2,5 \%$ & $2,4 \%$ \\
Abr-2019 & $570.968,64$ & $0,30 \%$ & $1,80 \%$ & $202.487,80$ & $3,2 \%$ & $3,1 \%$ \\
Jul-2019 & $598.943,07$ & $0,60 \%$ & $1,60 \%$ & $189.596,00$ & $4,7 \%$ & $4,5 \%$ \\
Oct-2019 & $611.766,54$ & $0,50 \%$ & $1,30 \%$ & $186.312,87$ & $3,1 \%$ & $3,0 \%$ \\
Ene-2020 & $663.709,86$ & $0,50 \%$ & $1,90 \%$ & $200.485,80$ & $2,3 \%$ & $2,2 \%$ \\
Abr-2020 & $577.968,93$ & $0,60 \%$ & $1,80 \%$ & $189.316,35$ & $4,6 \%$ & $4,4 \%$ \\
Jul-2020 & $585.633,51$ & $0,40 \%$ & $1,60 \%$ & $206.132,58$ & $1,8 \%$ & $1,7 \%$ \\
\hline Sourc: & Own $\%$ & & &
\end{tabular}

Source: Own elaboration

\subsection{Lotka-Volterra Model}

Logistical growth is related to exponential growth, in fact for minimum values of the magnitude that presents logistical growth, this is very similar to exponential (Ramirez, 2017). However, after a certain period the curve adequately represents a prediction of gross domestic product: at the beginning these spread rapidly, each supply is susceptible to transfer the demand 
to the period after it (Ulate, 2018). This typical application of the logistics equation is a common model of population growth according to which:

- The reproduction rate is proportional to the existing population.

- $\quad$ The reproduction rate is proportional to the amount of resources available.

The second term adjusts, therefore, the fairness of available resources, which tends to limit population growth (Cunha, Cândido, Oliveira and Penna, 2017). If P represents the subsequent GDP and t represents time, this model is formalized by the differential equation:

$$
\frac{d P}{d t}=r P\left(1-\frac{P}{K}\right) \quad \text { Eq. (1) }
$$

Where the constant (r) defines the rate of variability and (K), is the capacity of persistence. The general solution to this equation is a logistic function. With an initial GDP:

$$
P(t)=\frac{K P_{0} e^{r t}}{K+P_{0}\left(e^{r t}-1\right)} \quad \text { Eq. (2) }
$$

\subsection{ARIMA Model}

The ARIMA model is an econometric methodology reflected in dynamic differential models that use time series data (Blanco \& Hancco 2020). The systematic used in ARIMA models was first described by mathematician George Edward Pelham Box and engineer Gwilym Meirion Jenkins in 1970 in their book: Time Series Analysis, Prediction and Control.

For this research, the ARIMA model is fitted with an autoregressive term (AR (1)) and a seasonal differentiation term with a seasonal period of 12, the applied mathematical model is:

$$
\mathrm{Yt}-\mathrm{Yt}-12=\gamma+\Phi(\mathrm{Yt}-1-\mathrm{Yt}-12-1) \mathrm{Eq} . \text { (3) }
$$

Where:

$\mathrm{Yt} \quad$ real value in time $\mathrm{t}$

$\Phi \quad$ term autoregressive

$\gamma \quad$ constant term

Then it continues to be applied period by period until it reaches 12 and; calculate the gross domestic product GDP. 


\subsection{The Holt-Winters Statistician}

The Holt-Winters multiplicative statistic is a robust technique for predicting time series with an additive tendency (Mejía and Gonzales, 2019). The recursive form of the Holt-Winters triple exponential smoothing equation is expressed as:

$$
\begin{array}{cc}
F_{t}(m)=\left(S_{t}+m b_{t}\right) C_{t-L+m} & \text { Eq. (4) } \\
S_{t>L}=\propto+\frac{X_{t}}{C_{t-L}}+(1-\propto)\left(S_{t-1}+b_{t-1}\right) & \text { Eq. (5) } \\
b_{t>L}=\varepsilon\left(S_{t}-S_{t-1}\right)+(1-\varepsilon) b_{t-1} & \text { Eq. (6) } \\
C_{t>L}=\theta\left(\frac{X_{t}}{S_{t}}\right)+(1-\theta) C_{t-L} & \text { Eq. (7) }
\end{array}
$$

Where:

$\mathrm{X}_{\mathrm{t}}$ is the value of the time series in time $\mathrm{t}$.

$\mathrm{L}$ is the length of the season or duration.

$\mathrm{S}_{\mathrm{t}}$ is an estimate of the smoothing of the level component.

$b_{t}$ is an estimate of the smoothing of the trend component.

$\mathrm{C}_{\mathrm{t}}$ is an estimate of the smoothing of the seasonal index component.

$\alpha$ is the level of smoothing coefficient.

$\varepsilon$ is the trend of the smoothing coefficient.

$\Theta$ is the seasonal smoothing coefficient.

$\mathrm{F}_{\mathrm{t}}(\mathrm{m})$ is the predicted smoothing value in the forward step $\mathrm{m}$ for $\mathrm{X}$ at time $\mathrm{t}$.

Three simple exponential series, not dependent on level, trend and season, were assessed. They are interdependent in the sense that all three components must be updated every period (Dimitrov, Kraseta, Dimitrov and Parvanov, 2018). The study started from the historical GDP variation for the United Kingdom and Peru with a 12-quarter forward projection. 


\section{Results and discussion}

\subsection{GDP-Brexit Analysis: United Kingdom}

Based on the historical GDP variation for the United Kingdom and Peru in Table 1, five mathematical models were applied to make decisions about the indicator that is directly affected by Brexit, given the variability in the quarters evaluated (Guera et al., 2019). It was projected through these, for twelve periods from October 2020 to July 2023. The following are the standardized results of the model:

(A) ARIMA $(1,0,0)$ with constant

(B) Constant average $=606276$

(C) Lotka - Volterra $P(t)=\frac{575730 P_{0} e^{r t}}{575730+P_{0}\left(e^{r t}-1\right)}$

(D) Simple moving average of 3 terms

(E) Simple exponential smoothing with alpha $=0,0581$

Table 2 compares the results of five different forecasting models for gross domestic product (GDP). The model with the lowest mean absolute error (MAE) is model A. The model with the lowest percentage of mean absolute error (MAPE) is model A. MAPE estimates the average percentage of forecasting error one step ahead for GDP. The RMSE value expresses the amount of error between the data, i.e. between the prediction and the actual values (Gómez \& Aguayo, 2019). For example, for model (A) the error is $4,00932 \%$ and so on with all models. Also the model (C) is one of the most accurate with an average error of 4,04754\%.

Therefore, both the ARIMA model and the Lotka-Volterra trend predict a GDP growth value with an average accuracy of $96 \%$ for both.

Table 2. Forecast for GDP-UK

\begin{tabular}{|c|c|c|c|c|c|}
\hline Model & RMSE & MAE & MAPE & ME & MPE \\
\hline (A) & 31998,9 & 23937,3 & 4,00932 & 113,463 & $-0,243751$ \\
\hline (B) & 31924,4 & 24676,2 & 4,13619 & $-8,44011 E-11$ & $-0,27564$ \\
\hline (C) & 32524,9 & 24221,2 & 4,04754 & 804,798 & $-0,136814$ \\
\hline (D) & 38376,6 & 30663,8 & 5,12473 & $-1365,42$ & $-0,555278$ \\
\hline (E) & 32986,0 & 25492,8 & 4,26267 & 1720,42 & 0,000475556 \\
\hline
\end{tabular}


Source: Own elaboration.

Table 3 shows the results of the Holt-Winters prediction, as a variation for GDP in millions of dollars per quarter. By July 2023 it is estimated that the GDP will reach a threshold of between US\$ 495291,786 to US\$ 654181,554 in growth over the current value. This model together with ARIMA and Curtva-S are within the range of prediction of the GDP, giving reliability to the study.

The GDP results confirm a downward trend forecast for the period 2021-2023; in line with economic forecasts and analyses that Britain will be, in the short and medium term, the big loser of Brexit. This was stated by ten Nobel laureates in the statement against Brexit, published in The Guardian newspaper, citing that "anyone who votes for Brexit with their heart will regret it with their brain" (El País, 2016). In theory, the ARIMA forecast explained a quarterly decline in GDP measured in US\$2000,00; this in turn will influence the per capita income of the population and overall supply and demand in the UK's national accounts. Britain's exit would reduce GDP by up to three percentage points under the assumption of an estimated cost of US\$ 920 per capita and a measured decline in income of four per cent. Accordingly, Oxford Economics (2021) estimated that Brexit will be 2/3 the size of the financial crisis of London's past, making Britain a net loser after the break-up of the European Union.

Table 3. Forecast of GDP-UK, for the period September 2020-June 2023

\begin{tabular}{cccccc}
\hline Period & GDP M\$ & $\begin{array}{c}\text { Holt- } \\
\text { Winters(GD } \\
\text { P MUS\$) }\end{array}$ & Waste & $\begin{array}{c}\text { Lower limit } \\
\text { (95\%) }\end{array}$ & $\begin{array}{c}\text { Upper limit } \\
\text { (95\%) }\end{array}$ \\
\hline Oct-2015 & 614212,830 & & & & \\
Ene-2016 & 629467,740 & 614212,830 & 15254,910 & & \\
Abr-2016 & 591012,180 & 614536,336 & $-23524,156$ & & \\
Jul-2016 & 592394,220 & 614359,691 & $-21965,471$ & & \\
Oct-2016 & 623169,360 & 613719,208 & 9450,152 & & \\
Ene-2017 & 632604,060 & 613280,976 & 19323,084 & & \\
Abr-2017 & 637965,900 & 613251,729 & 24714,171 & & \\
Jul-2017 & 626089,860 & 613744,964 & 12344,896 & & \\
Oct-2017 & 592691,220 & 614497,917 & $-21806,697$ & & \\
Ene-2018 & 603207,000 & 614787,386 & $-11580,386$ & & \\
Abr-2018 & 624554,370 & 614833,105 & 9721,265 & & \\
Jul-2018 & 519808,410 & 615085,953 & $-95277,543$ & & \\
Oct-2018 & 645976,980 & 613317,463 & 32659,517 & &
\end{tabular}




\begin{tabular}{crrrrr} 
Ene-2019 & 583366,410 & 612249,577 & $-28883,167$ & & \\
Abr-2019 & 570968,640 & 610566,431 & $-39597,791$ & & \\
Jul-2019 & 598943,070 & 608045,973 & $-9102,903$ & & \\
Oct-2019 & 611766,540 & 605335,800 & 6430,740 & & \\
Ene-2020 & 663709,860 & 602762,766 & 60947,094 & & \\
Abr-2020 & 577968,930 & 601481,677 & $-23512,747$ & & \\
Jul-2020 & 585633,510 & 599696,841 & $-14063,331$ & & \\
Oct-2020 & & 597615,744 & & 525865,801 & 669365,687 \\
Ene-2021 & 595535,828 & & 523769,753 & 667301,904 \\
Abr-2021 & & 593455,912 & & 521625,601 & 665286,224 \\
Jul-2021 & & 591375,997 & & 519401,552 & 663350,441 \\
Oct-2021 & 589296,081 & & 517066,280 & 661525,881 \\
Ene-2022 & & 587216,165 & & 514589,325 & 659843,004 \\
Abr-2022 & & 585136,249 & & 511941,606 & 658330,892 \\
Jul-2022 & & 583056,333 & & 509095,996 & 657016,671 \\
Oct-2022 & & 580976,417 & & 506027,908 & 655924,926 \\
Ene-2023 & & 576896,501 & & 502715,848 & 655077,155 \\
Abr-2023 & 574736,670 & 499141,852 & 654491,319 \\
Jul-2023 & & & 495291,786 & 654181,554 \\
\hline
\end{tabular}

Source: Own elaboration.

Figure 1 shows the Holt-Winters exponential growth model for GDP in the United Kingdom. The red line indicates the stability in growth of the indicator from October 2020 to July 2023; appreciating an increase of 574736,670 thousand US dollars in relation to the previous period. The blue line shows the historical growth since the beginning of the Brexit since July 2016. 


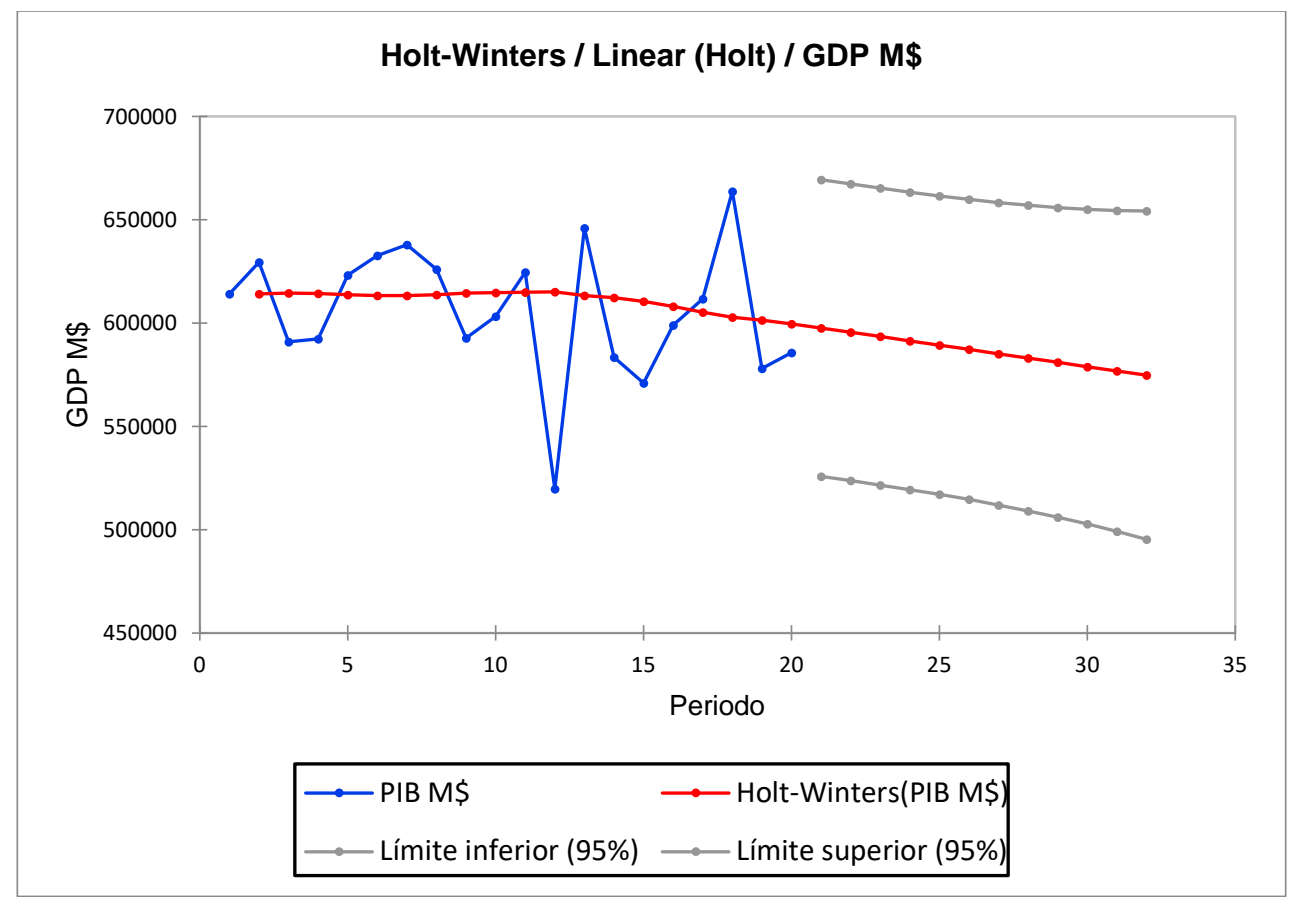

Figure 1. Holt-Winters threshold prediction model in the UK

Source: Own elaboration.

\subsection{GDP-Brexit Analysis: Peru}

In Table 4, the MAPE estimates the average percentage of forecasting error to be 36,713, a step ahead of the GDP, indicating that the forecast is accurate at a percentage difference of 63,287. The RMSE value for the series is 0,016 and shows the amount of error between the data, i.e., between the forecast and the actual values. In that sense, the forecast for the period from the third quarter of 2020 to the second quarter of 2023 quantifies a model accuracy of 98\%.

Table 4. Goodness of fit for the Holt-Winters Model

\begin{tabular}{lr}
\hline \multicolumn{1}{c}{ Statistical } & Value \\
\hline Observations & 20 \\
GL & 16 \\
SEC & 0,004 \\
MEC & 0,000 \\
RMSE & 0,016 \\
MAPE & 36,713 \\
MPE & 26,832 \\
MAE & 0,012 \\
R & \\
Iterations & Yes \\
\hline
\end{tabular}


Source: Own elaboration.

Table 5 shows the results of the prediction in variation for the GDP in millions of dollars per quarter. By July 2023 it is estimated that the GDP will reach a threshold of between US\$ 179744,874 to US\$ 247212,716 in growth over current value. The purpose is to show the increase or variation of the GDP for Great Britain with a focus on the economic framework generated by the phenomenon analysed proposed above all in the correlation between the economic and political reflection on the Brexit effect on the Europe-Peru relationship. In this sense, in a moderate scenario, Great Britain would protect part of its permanence in the single market and could therefore continue to enjoy the export of products and services at relatively low prices due to the devaluation of the pound. However, imports would decrease due to the excessive increase in the price of imports, leading to a tendency towards self-sufficiency and a high dependence on key commodities such as oil. According to experts, the GDP deficit will be 6,90\% and indicates that Britain will be a net borrower in the global economic context, depending on the good fortunes of foreign investors to finance its economy (Oxford Economics, 2021). In the context of the Peruvian economy, and at the local Latin American level, how does the UK's exit from the European Union affect Peru? Indeed, trade relations with the bloc are based on the Peru-EU free trade agreement and a long-standing bilateral investment agreement. Thus, with regard to the latter, as Semanario 948 points out, according to figures from ProInversión, in 2017, the British country was the second most important source of foreign direct investment in Peru, with US\$ 4336 million, only behind Spain (US\$ 4522 million), mainly destined for the mining, finance and telecommunications sectors, which accounted for 53\%, $17 \%$ and $8 \%$ of the total, respectively. It is also important to mention that, in 2018, trade with Great Britain represented 8\% of our trade with the EU (Confiep, 2019).

Table 5. Forecast of GDP-Peru, for the period September 2020-June 2023

\begin{tabular}{ccclcc}
\hline Period & GDP M\$ & $\begin{array}{c}\text { Holt- } \\
\text { Winters(GD } \\
\text { P M\$) }\end{array}$ & Waste & $\begin{array}{c}\text { Lower limit } \\
(95 \%)\end{array}$ & $\begin{array}{c}\text { Upper limit } \\
(95 \%)\end{array}$ \\
\hline Oct-2015 & 168985,320 & & & & \\
Ene-2016 & 172101,720 & 168985,320 & 3116,400 & &
\end{tabular}




\begin{tabular}{rrrrrl} 
Abr-2016 & 185804,080 & 169625,701 & 16178,379 & & \\
Jul-2016 & 187009,480 & 173032,142 & 13977,338 & & \\
Oct-2016 & 191684,717 & 176411,939 & 15272,778 & & \\
Ene-2017 & 172434,000 & 180425,665 & $-7991,665$ & & \\
Abr-2017 & 190826,000 & 180060,660 & 10765,340 & & \\
Jul-2017 & 176576,365 & 183339,726 & $-6763,362$ & & \\
Oct-2017 & 196209,108 & 183300,095 & 12909,013 & & \\
Ene-2018 & 189253,594 & 187124,948 & 2128,646 & & \\
Abr-2018 & 175614,000 & 189074,199 & $-13460,199$ & & \\
Jul-2018 & 180710,832 & 187876,144 & $-7165,312$ & & \\
Oct-2018 & 195978,302 & 187617,480 & 8360,822 & & \\
Ene-2019 & 180990,774 & 190360,725 & $-9369,951$ & & \\
Abr-2019 & 202487,800 & 189680,489 & 12807,311 & & \\
Jul-2019 & 189596,000 & 193310,882 & $-3714,882$ & & \\
Oct-2019 & 186312,868 & 193883,125 & $-7570,257$ & & \\
Ene-2020 & 200485,803 & 193565,401 & 6920,402 & & \\
Abr-2020 & 189316,349 & 196026,156 & $-6709,807$ & & \\
Jul-2020 & 206132,580 & 195868,147 & 10264,433 & & \\
Oct-2020 & & 199021,599 & & 176901,102 & 221142,095 \\
Ene-2021 & & 200335,889 & & 177753,202 & 222918,576 \\
Abr-2021 & & 201650,180 & & 178492,707 & 224807,652 \\
Jul-2021 & & 202964,470 & & 179113,556 & 226815,385 \\
Oct-2021 & & 204278,761 & & 179612,025 & 228945,497 \\
Ene-2022 & & 205593,051 & & 179986,584 & 231199,519 \\
Abr-2022 & & 206907,342 & & 180237,632 & 233577,052 \\
Jul-2022 & & 208221,633 & & 180367,154 & 236076,112 \\
Oct-2022 & & 209535,923 & & 180378,346 & 238693,501 \\
Ene-2023 & & 210850,214 & & 180275,261 & 241425,167 \\
Abr-2023 & & 212164,504 & & 180062,485 & 244266,524 \\
Jul-2023 & & 213478,795 & & 179744,874 & 247212,716 \\
\hline
\end{tabular}

Source: Own elaboration.

Figure 2 shows the Holt-Winters exponential growth model for GDP in the Republic of Peru. The red line indicates the stability of the indicator's growth from October 2020 to July 2023, appreciating a rise of $\$ 2,378,795$ thousand US dollars in relation to the previous period. The blue line shows the historical growth since the beginning of the Brexit since July 2016. 


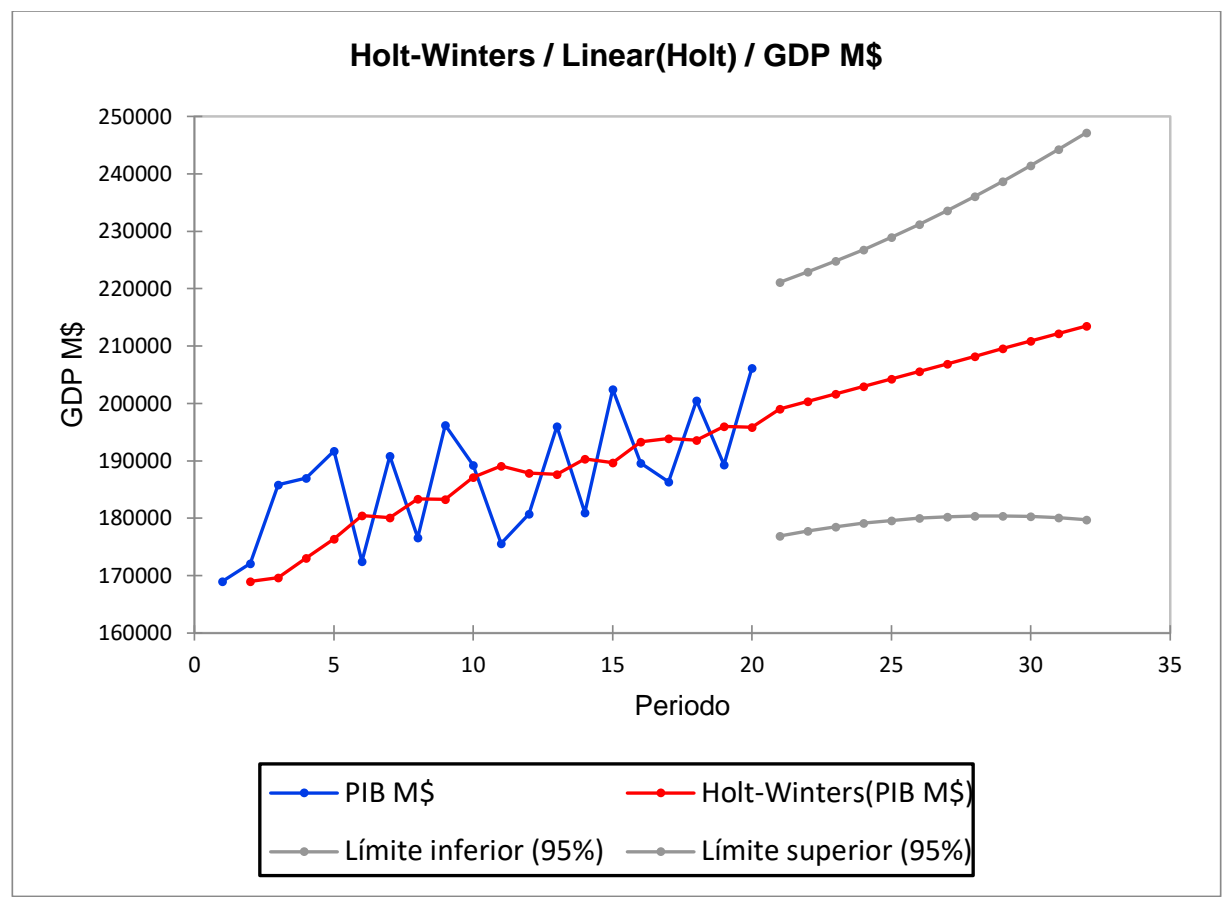

Figure 2. Holt-Winters threshold prediction model in Peru

Source: Own elaboration.

In summary, comparing the economic relationship of the United Kingdom and Peru measured in the gross domestic product (GDP) as the root of Brexit; the Republic of Peru will be the most benefited, because if we compare the Holt-Winters lines (GDP M\$) in Figures 1 and 2, the upward trend is more pronounced in mathematical terms of slope for Peru with an exponential growth of 8,99\% between Jul-2020 (US\$ 195868,147) and July-2023 (US\$ 213478,795). This result confirms Confiep's economic analysis (2019), according to Sunat figures, between 2014 and 2018, exports to the UK grew at an average annual rate of 3,7\%, from US\$ 607 million in 2014 to US\$ 704 million in 2018. Of the total exports in 2018, shipments of traditional products accounted for 42,1\%, with a value of US\$ 296 million. Meanwhile, non-traditional exports accounted for $57,9 \%$, with a value of US\$ 408 million, with those of the agricultural sector being the most representative, with US\$ 328 million. In summary, a possible exit of the United Kingdom from the European Union would imply maintaining a minimum average exponential growth of $8 \%$ in GDP, under the assumption of the Republic of Peru as a good foreign investor that will contribute to the finances of the British economy. 


\section{Conclusion}

From the question: Will Brexit as a political and economic project allow the Republic of Peru to increase the variability in terms of gross domestic product (GDP), the answer is yes. The organizational contradictions of the United Kingdom's exit from the European Union, Brexit, are translated into a special regime in the transaction costs of companies in cross-border trade within Europe and in particular we highlight the importance of the treaty agreed between the United Kingdom and Peru (Hearne, 2020; Bulmer, 2014). These costs are historically reflected in gross domestic product (GDP) (Daddow, 2019). This is where the mathematical models came in to answer the question. Comparing the economic relationship of the United Kingdom and Peru as measured in gross domestic product GDP as the root of Brexit; the Republic of Peru will benefit most. The upward trend of the indicator for Peru, is observed in the exponential growth of 8,99\% for the variability, between the period Jul-2020 and July-2023; from US\$ 195868,147 to US\$ $213478,795$.

In this sense, the increase or variation of the GDP for Great Britain was demonstrated with a focus on the economic framework generated by the phenomenon analyzed proposed above all in the correlation between the economic and political reflection on the Brexit effect on the EuropePeru relationship. In a moderate scenario, the UK would remain in the single market with the benefit of exporting products and services at relatively low prices due to the devaluation of the pound. Imports would decrease due to the excessive increase in the price of imports, leading to a trend towards self-sufficiency and a high dependence on key commodities such as oil. Negotiations for a post-Brexit trade agreement between Peru and the UK will continue to grow, and a major exit from the EU will guarantee continuity in the bilateral trade relationship once Brexit has taken place. At the same time, the UK has long confirmed its interest in the Comprehensive and Progressive Agreement for Trans-Pacific Partnership (CPTPP), as well as its support for Peru's candidacy to join the Organization for Economic Co-operation and Development (OECD).

As a final reflection, the outlook is one of concern for the UK's European partners, as they have no incentive to do so and, more importantly, it would be a very attractive exit that could be demanded by other states, producing a domino effect initiated by Brexit. 


\section{References}

1. Adler, R., Galpin, C. and Rosamond, B., 2017. Performing Brexit: How a post-Brexit world is imagined outside the United Kingdom. The British Journal of Politics and International Relations, 19(3), pp.573-591. doi: 10.1177\%2F1369148117711092.

2. Beaumont, P., 2017. Brexit, Retrotopia and the perils of post-colonial delusions. Global Affairs, 3(4-5), pp.379-390. doi: 10.1080/23340460.2018.1478674.

3. Blanco, L., y Hancco, R., 2020. Modeling and forecasting international tourism demand in Puno-Peru. Revista Brasileira de Pesquisa em Turismo 14(1), pp. 34-55. doi: 10.7784/rbtur.v14i1.1606.

4. Bulmer, S., 2014. Germany and the Eurozone Crisis: Between Hegemony and Domestic Politics. West European Politics, $\quad 37(6), \quad$ pp.1244-1263. doi: 10.1080/01402382.2014.929333.

5. Ceballos, L., and Rodríguez, L. 2020. Estrategia para el perfeccionamiento de la asignatura Elementos de Investigación Cualitativa en Salud. Revista de Ciencias Médicas de Pinar del Río, 24(2), pp. 215-225. http://scielo.sld.cu/scielo.php?script=sci_arttext\&pid=S156131942020000200215\&lng=es\&tlng=es.

6. Confiep, 2021. Brexit: ¿Cómo afecta al Perú la salida del Reino Unido de la Unión Europea? - CONFIEP. [online] CONFIEP. Available at: $<$ https://www.confiep.org.pe/noticias/actualidad/brexit-como-afecta-al-peru-la-salida-delreino-unido-de-la-union-europea> [Accessed 15 June 2021].

7. Cunha, J., Cândido, L., Oliveira, F. and Penna, A., 2017. Evolução dos processos físicos nos modelos de dinâmica de populações. Revista Brasileira de Ensino de Física, 39(3). doi: 10.1590/1806-9126-rbef-2016-0254.

8. Daddow, O., 2019. GlobalBritain ${ }^{\mathrm{TM}}$ : the discursive construction of Britain's post-Brexit world role. Global Affairs, 5(1), pp.5-22. doi: 10.1080/23340460.2019.1599297.

9. Dimitrov, P., Kraseta, R., Dimitrov, B. and Parvanov, P., 2018. Bulgarian tourism and the problem of poverty in Bulgaria. Tourism \& Management Studies, 14(2), pp.45-52. doi: 10.18089/tms.2018.14205. 
10. El País, 2016. Premios Nobel británicos alertan del peligro del 'Brexit' para la ciencia. [online]

Available

at: https://elpais.com/internacional/2016/10/06/actualidad/1475774168_413567.html [Accessed 15 June 2021].

11. Gidron, N., and Hall, P. A., 2017. The politics of social status: economic and cultural roots of the populist right. The British journal of sociology, 68(1), pp. 57-84. doi: 10.1111/14684446.12319.

12. Gómez A.M., Estruch, V., 2019. Valoración económica de los servicios ecosistémicos marinos: un caso de estudio de La Safor, Golfo de Valencia, España. Ecosistemas 28(2), pp. 100-108. doi: 10.7818/ECOS.1644.

13. Guera, O., Silva, J., Ferreira, R., Álvarez Lazo, D. and Barrero Medel, H., 2019. Modelos matemáticos para la determinación del turno óptimo en plantaciones forestales. Madera y Bosques, 25(1). doi: 10.21829/myb.2019.2511636.

14. Hearne, D., 2020. A spatial analysis of the Brexit vote in the West Midlands. Regional Studies, Regional Science, 7(1), pp.232-243. doi: 10.1080/21681376.2020.1782255.

15. Hecht, C., 2016. The shifting salience of democratic governance: Evidence from the United Nations General Assembly General Debates. Review of International Studies, 42(5), pp.915-938. doi: 10.1017/S0260210516000073.

16. Horna, I., 2020. Perspectivas del financiamiento corporativo y el mercado de valores del Perú. Retos, 10(19), pp.135-152. doi: 10.17163/ret.n19.2020.08.

17. Mejía, E., and Gonzales, S., 2019. Prediction of residential electricity consumption in the Cajamarca region using Holt -Winters models. Ingeniería Energética, 40(3), pp. 181-191. [online] Available at: http://scielo.sld.cu/scielo.php?script=sci_arttext\&pid=S181559012019000300181\&lng=es\&tlng=es, [Accessed 15 June 2021].

18. Norris, P., and Inglehart, R., 2019. Cultural Backlash: Trump, Brexit, and Authoritarian Populism. Cambridge: Cambridge University Press. doi: 10.1017/9781108595841.

19. Oehler, A., Horn, M. and Wendt, S., 2017. Brexit: Short-term stock price effects and the impact of firm-level internationalization. Finance Research Letters, 22, pp.175-181. doi: 10.1016/j.frl.2016.12.024. 
20. Oxford Economics, 2021. The Economic Impact of Brexit. [online] Oxford Economics. Available at: <https:/www.oxfordeconomics.com/recent-releases/assessing-theeconomic-implications-of-brexit> [Accessed 15 June 2021].

21. Ramírez, G., 2017. Theoretical study of the action of ionizing radiation on the population dynamics of cancer cells. Revista Boliviana de Física, 31(31), pp. 25-34 http://www.scielo.org.bo/scielo.php?script=sci_abstract\&pid=S156238232017000200004\&lng=es\&nrm=iso\&tlng=en.

22. Sowels, N., 2017. Brexit and UK-Based Financial Services. Revue française de civilisation britannique, 22(2). doi: 10.4000/rfcb.1331.

23. Ulate, F., 2018. Sentimiento Bursátil Como Sistema Dinámico. Revista de Matemática: Teoría y Aplicaciones, 25(1), p.61. doi: 10.15517/rmta.v1i25.32232.

24. Vikram Philip, S., 2021. Bloomberg - Are you a robot? [online] Bloomberg.com. Available at: <https://www.bloomberg.com/news/articles/2021-01-13/ford-hikes-prices-of-severalu-k-models-due-to-brexit-tariffs> [Accessed 15 June 2021].

25. Virdee, S. and McGeever, B., 2017. Racism, Crisis, Brexit. Ethnic and Racial Studies, 41(10), pp.1802-1819. doi: 10.1080/01419870.2017.1361544. 